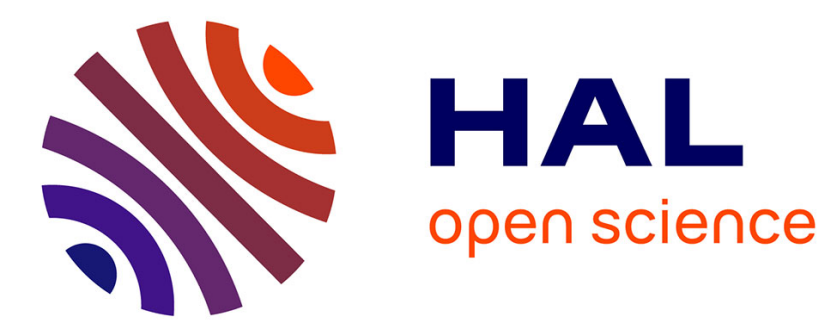

\title{
Salmonella serovar specific upregulation of porcine defensins 1, 2 in a jejunal epithelial cell line
}

Edwin J.A. Veldhuizen, Ingrid Koomen, Ton Ultee, Albert van Dijk, Henk P. Haagsman

\section{To cite this version:}

Edwin J.A. Veldhuizen, Ingrid Koomen, Ton Ultee, Albert van Dijk, Henk P. Haagsman. Salmonella serovar specific upregulation of porcine defensins 1,2 in a jejunal epithelial cell line. Veterinary Microbiology, 2009, 136 (1-2), pp.69. 10.1016/j.vetmic.2008.09.072 . hal-00532510

\section{HAL Id: hal-00532510 https://hal.science/hal-00532510}

Submitted on 4 Nov 2010

HAL is a multi-disciplinary open access archive for the deposit and dissemination of scientific research documents, whether they are published or not. The documents may come from teaching and research institutions in France or abroad, or from public or private research centers.
L'archive ouverte pluridisciplinaire HAL, est destinée au dépôt et à la diffusion de documents scientifiques de niveau recherche, publiés ou non, émanant des établissements d'enseignement et de recherche français ou étrangers, des laboratoires publics ou privés. 


\section{Accepted Manuscript}

Title: Salmonella serovar specific upregulation of porcine defensins 1,2 in a jejunal epithelial cell line

Authors: Edwin J.A. Veldhuizen, Ingrid Koomen, Ton Ultee, Albert van Dijk, Henk P. Haagsman

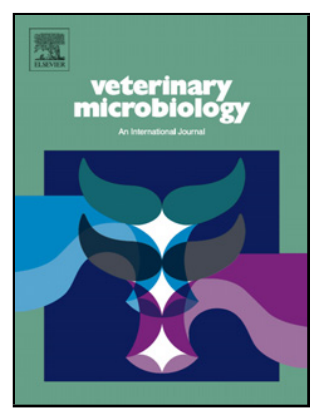

PII:

S0378-1135(08)00448-3

DOI: doi:10.1016/j.vetmic.2008.09.072

Reference: VETMIC 4214

To appear in: $\quad$ VETMIC

Received date: $\quad 23-6-2008$

Revised date: $\quad 10-9-2008$

Accepted date: $\quad$ 19-9-2008

Please cite this article as: Veldhuizen, E.J.A., Koomen, I., Ultee, T., van Dijk, A., Haagsman, H.P., Salmonella serovar specific upregulation of porcine defensins 1, 2 in a jejunal epithelial cell line, Veterinary Microbiology (2008), doi:10.1016/j.vetmic.2008.09.072

This is a PDF file of an unedited manuscript that has been accepted for publication. As a service to our customers we are providing this early version of the manuscript. The manuscript will undergo copyediting, typesetting, and review of the resulting proof before it is published in its final form. Please note that during the production process errors may be discovered which could affect the content, and all legal disclaimers that apply to the journal pertain. 
1 Salmonella serovar specific upregulation of porcine defensins 1 and 2 in a

2 jejunal epithelial cell line.

3

4 Edwin J.A. Veldhuizen ${ }^{a^{*}}$, Ingrid Koomen ${ }^{\mathrm{a}}$, Ton Ultee ${ }^{\mathrm{b}}$, Albert van Dijk ${ }^{\mathrm{a}}$, Henk P. Haagsman ${ }^{\mathrm{a}}$

$6 \quad{ }^{\mathrm{a}}$ Department of Infectious Diseases and Immunology \& ${ }^{\mathrm{b}}$ Center for Cell Imaging, Department of

7 Biochemistry \& Cell Biology, Faculty of Veterinary Medicine, Utrecht University, Utrecht, The

8 Netherlands.

9

$10 *$ Corresponding author: Department of Infectious Diseases \& Immunology, Faculty of Veterinary

11 Medicine, Utrecht University, P.O. Box 80.165, 3508 TD, Utrecht, The Netherlands. Tel +31 30

12 2535361, Fax: + 3130 2532333, E.J.A.Veldhuizen@uu.nl 


\section{Abstract}

14 Defensins are antimicrobial important effector peptides of the innate immune system, which provides

15 protection against bacterial infections in the intestine. Salmonella Choleraesuis and Salmonella

16 Typhimurium are the most commonly isolated serovars in pig, but disease outcome is dependent on

17 the Salmonella serovar. These infections are a serious problem for the swine industry and are also

18 posing a major threat to public health because of Salmonella-related food-borne illnesses in human.

19 To understand the innate immune response of pigs upon Salmonella infections, we studied the effect

20 of these Salmonella serovars in the porcine ileal epithelial cell line IPEC-J2 on defensin gene

21 expression. With the use of scanning electron microscopy, we first visualized the surface

22 characteristics of this cell line, and captured the invasion of Salmonella into the epithelial cell. Gene

23 expression levels of porcine $\beta$-defensin 1 and 2 were both induced upon Salmonella Typhimurium

24 infection but Salmonella Choleraesuis had no effect. Invasion, adhesion and defensin susceptibility of

25 both serovars were similar, which could not explain the observed difference in host response to these

26 Salmonellae. In addition, induction of defensins was dependent on viability of Salmonella

27 Typhimurium, since Salmonella cell- or secreted components had no effect on defensin gene

28 expression. These results provide further insight into the porcine innate immune response towards

29 Salmonella infections, and could partially explain the different epidemiology of Salmonella infections

30 in pig.

31 Keywords: Innate immunity, gut, antimicrobial peptide, pig, Salmonella 
Introduction.

33 Salmonella infections are an important source of food-born illnesses and therefore a major public

34 health concern. In addition, Salmonellosis is a major cause of disease in pigs and a serious problem

35 for the swine industry. In pig, Salmonella enterica serovar Choleraesuis (S. Choleraesuis) and

36 Salmonella enterica serovar Typhimurium DT104 (S. Typhimurium) are the most frequently isolated

37 serovars (Chiu et al., 2004, Schwartz, 1999). In contrast to $S$. Typhimurium, which is able to infect a

38 very broad range of hosts including humans, $S$. Choleraesuis appears to be specifically adapted to pig

39 (Chiu et al., 2004). Interestingly, these serovars produce different patterns of disease in growing pigs:

$40 S$. Typhimurium usually causes mild enteritis and self-limiting diarrhea, while $S$. Choleraesuis leads to

41 systemic disease such as septicaemia (Fraser et al., 2007, Schwartz, 1999).

42 In the intestine, the first line of defense against invading pathogens, such as Salmonella, is provided

43 by the innate immune system (Beutler, 2004). Part of this immune response is the release of

44 antimicrobial peptides (AMPs) into the lumen of the intestinal tract. These peptides are capable of

45 directly killing a wide variety of bacterial and viral pathogens. One major subclass of AMPs is the

46 group of $\beta$-defensins (Lehrer, 2004). Up to date, 12 porcine $\beta$-defensins (pBDs) have been identified

47 and the expression of pBD-1 and pBD-2 in the small intestine of the pig has recently been described

48 (Sang et al., 2006, Veldhuizen et al., 2007).

49 In order to study the effect of Salmonella infection on defensin regulation in the porcine GI-tract we

50 used the porcine cell line IPEC-J2. These cells are derived from porcine jejunum and have

51 demonstrated to possess many of the characteristics attributed to intestinal epithelial cells in vivo

52 (Schierack et al., 2006). Infection of intestinal cells with $S$. Typhimurium resulted in a clear

53 upregulation of both pBD-1 and pBD-2 mRNA levels after 24h of infection. Furthermore, this

54 upregulation required viable bacteria and was independent of $S$. Typhimurium secreted components.

55 In contrast, infection of IPEC-J2 cells with $S$. Choleraesuis had no or little detectable effect on

56 defensin regulation. 


\section{2. Materials and methods}

58

59

60

61

62

63

64

65

66

67

68

69

70

71

72

73

74

75

76

77

78

79

80

81

\subsection{Bacterial strains and culture conditions}

Overnight cultures of Salmonella enterica serovar Typhimurium DT104 (Hendriksen et al., 2004), and 4 field strains of Salmonella Choleraesuis (denoted as S. Choleraesuis 994-997) were prepared freshly for every experiment by cultivation from a frozen stock at $37{ }^{\circ} \mathrm{C}$ in Trypticase Soy Broth (TSB, Oxoid Limited). Before use in adhesion, invasion and infection experiments, an overnight culture was subcultured 1:100 and incubated for $2 \mathrm{~h}$ at $37^{\circ} \mathrm{C}$. Bacteria were then collected in the exponential phase, spun down and resuspended in IPEC-J2 cell culture medium at $1 \times 10^{8}$ colony forming units (CFU) /ml.

\subsection{Cell culture}

The IPEC-J2 cell line (Schierack et al., 2006) was maintained in 50\% Dulbecco's Modified Eagle Medium and 50\% Nutrient Mixture F12 (Ham) (1:1 DMEM/F12) (GIBCO, Invitrogen life Technologies, Carlsbad, CA), supplemented with (10 U/ml) penicillin, (10 mg/ml) streptomycin, (2 $\mathrm{mM}$ ) L-glutamine and 5\% fetal bovine serum (vol/vol) (all provided by GIBCO, Invitrogen life Technologies, Carlsbad, CA). Cells were grown in monolayers at $37{ }^{\circ} \mathrm{C}$ in $5 \% \mathrm{CO}_{2}$ atmosphere. Medium was changed every other day and cells were passed once a week. For infection experiments, cells were cultured in 12-well cell culture plates (surface area $=4.75 \mathrm{~cm}^{2}$ per well; Costar, Corning Incorporated, Corning, NY) and grown to confluent monolayers in 7 days. In all experiments IPEC-J2 cells were used between passages 80 and 100.

\subsection{Scanning electron microscopy (SEM).}

IPEC-J2 cells were seeded on plastic slides in 12-well tissue-culture plates. After the cells reached confluency, cells were incubated with $S$. Typhimurium or $S$. Choleraesuis for $1 \mathrm{~h}$. The cells were then washed three times with plain DMEM/F12 and incubated with Karnovskys glutaraldehyde fixative for a week. Subsequently, the following fixation, wash and rehydration steps were performed: washing with $0.1 \mathrm{ml}$ of cacodylate buffer ( $\mathrm{pH} 7.4$ ); post-fixation with $2 \% \mathrm{OsO}_{4}$ in $0.1 \mathrm{ml}$ cacodylate buffer 
82 (pH 7.4) for $2 \mathrm{~h}$. Rinsing in $0.1 \mathrm{M}$ cacodylate for $10 \mathrm{~min}$ and additionally 6 times in distilled water for $8330 \mathrm{~min}$; incubation in $2 \%$ tannic acid for $1 \mathrm{~h}$; washing 6 times $1 \mathrm{~h}$ in distilled water; fixation in $2 \%$

$84 \mathrm{OsO}_{4}$ buffered in $0.1 \mathrm{M}$ cacodylate buffer $\mathrm{pH} 7.4$ for $1 \mathrm{~h}$; dehydration using serial solutions of $50 \%$,

$8570 \%, 80 \%, 96 \%$, and 100\% acetone, and critical-point-dried using a Bal-Tec CPD 030 system.

86 Finally, the samples were coated with platinum to a thickness of $10 \mathrm{~nm}$ and examined using a Philips

87 XL 30 SFEG scanning electron microscope.

$88 \quad 2.4$ Adhesion and invasion of Salmonella.

89 IPEC-J2 cells were grown to confluency in twelve-well tissue-culture plates, washed three times with

90 antibiotic free medium, and incubated with $1 \mathrm{ml}$ plain DMEM/F12 medium (without serum, L-

91 Glutamine or antibiotics) containing $1 \times 10^{8} \mathrm{CFU} / \mathrm{ml}$ bacteria for $1 \mathrm{~h}$ at $37^{\circ} \mathrm{C}$. The monolayers were

92 washed three times with plain media and lyzed in 1\% Triton-X100 in PBS at room temperature for 5

$93 \mathrm{~min}$ in order to release the bacteria. The suspensions were serially diluted and $100 \mu \mathrm{l}$ of each dilution

94 was plated on Trypticase Soy Agar (TSA, Oxoid Limited). The plates were incubated for $24 \mathrm{~h}$ at 37

$95{ }^{\circ} \mathrm{C}$. Numbers of cell-associated bacteria were calculated as total (adhering and intracellular) bacterial

96 CFU. In the invasion assay, the IPEC-J2 monolayers in the wells were washed once with $1 \mathrm{ml}$ warm

97 plain medium after $1 \mathrm{~h}$ incubation with bacteria and then incubated for $2 \mathrm{~h}$ with $1 \mathrm{ml}$ of $300 \mu \mathrm{g} / \mathrm{ml}$

98 colistin in warm plain DMEM/F12 to kill extracellular bacteria. Cells were washed three times with

99 plain DMEM/F12, and finally lyzed in $1 \%$ Triton X-100. The number of intracellular bacteria was

100 determined by colony-plating as described above.

1012.5 Susceptibility of Salmonella towards porcine $\beta$-defensin 2.

102 The antimicrobial activity of a synthetic peptide (Genosphere Biotechnologies, Paris, France)

103 corresponding to the mature 37 form of $\mathrm{pBD}-2$

104 (DHYICAKKGGTCNFSPCPLFNRIEGTCYSGKAKCCIR ) was assessed against $S$. Typhimurium

105 and $S$. Choleraesuis 994, as described before (Veldhuizen et al., 2008). In short, $25 \mu 12.10^{6} \mathrm{CFU} / \mathrm{ml}$

106 mid-logarithmic bacteria were incubated in $5 \mathrm{mM}$ phosphate, $\mathrm{pH} 7.0,1 / 200 \mathrm{TSB}$ with $25 \mu \mathrm{pBD} 2(0-$ 
$107256 \mu \mathrm{g}$ ) for $3 \mathrm{~h}$ at $37^{\circ} \mathrm{C}$. Subsequently, $200 \mu \mathrm{l} \mathrm{TSB}$ was added, further diluted 10-1000 fold in TSB

108 and transferred onto TSA plates. After $24 \mathrm{~h}$ incubation at $37^{\circ} \mathrm{C}$ colonies were counted.

1092.6 Infection of IPEC-J2 cells with Salmonella.

110 IPEC-J2 cells were grown to confluency in complete IPEC-J2 medium as described above and

111 infected with $1 \mathrm{ml}$ of $1 \times 10^{8} \mathrm{CFU} / \mathrm{ml}$ bacteria in plain DMEM/F12 for $3 \mathrm{~h}$. After incubation, cells

112 were washed twice and incubated with fresh complete medium containing $300 \mu \mathrm{g} / \mathrm{ml}$ colistin. After 6

113 and $24 \mathrm{~h}$ (and in initial experiments also after $12 \mathrm{~h}$ ) post infection, IPEC-J2 cells were dissolved in 1

$114 \mathrm{ml} \mathrm{TRIzol}{ }^{\circledR}$ (Invitrogen life technologies, Carlsbad, CA) for quantitative PCR analysis.

1152.7 Effect of viability of bacteria on defensin gene expression.

$116 S$. Typhimurium were grown to log phase and collected as described above and resuspended in IPEC-

$117 \mathrm{~J} 2$ medium. The bacteria were then subjected to one of the following treatments: 1) incubation at 80

$118{ }^{\circ} \mathrm{C}$ for $60 \mathrm{~min}$. 2) Incubation in IPEC-J2 medium containing $1 \mathrm{mg} / \mathrm{ml}$ colistin, or 3) incubation in

119 IPEC-J2 medium (without antibiotics) for $1 \mathrm{~h}$, followed by filtration $(0.45 \mu \mathrm{m}$ pore size) to remove

120 bacteria. Subsequently, the medium containing the killed bacteria (treatment 1 and 2), or the

121 Salmonella secreted proteins were used in the IPEC-J2 infection experiments. A small portion of the

122 solution containing the treated bacteria was serially diluted and colony-plated on TSA to detect the

123 presence of viable $S$. Typhimurium.

1242.8 Quantitative PCR.

125 Total cellular RNA was isolated from cell cultures using TRIzol as recommended by the suppliers. An

126 extra wash step with ice cold $70 \%$ ethanol was performed to remove the final traces of organic

127 solvents. Purity and quality of the RNA extracts was checked on $1 \%$ agarose gels and using UV

128 absorption at 260/280 nm. Approximately $500 \mathrm{ng}$ RNA was used to produce cDNA, using iScript

129 (Bio-rad Laboratories BV, Veenendaal, The Netherlands) according to the manufacturer's

130 recommendations. Quantitative PCR (qPCR) was performed on cDNA samples using a qPCR

131 mastermix for Primer-Probe reactions (RT-QP2X-03, Eurogentec Nederland b.v., The Netherlands). 
132 All qPCR reactions were performed according to the manufacturer's recommendation, using gene 133 specific primers and probes at concentrations depicted in table 1. Probes were labeled with 5' FAM 134 (pBD-1 and HPRT) or 5' Yakima Yellow (pBD-2) and 3' Deep Dark Quencher 1 (all probes). All

135 qPCR reactions were performed in $25 \mu 1$ on an ABI Prism 7000 sequence detection system (Applied

136 Biosystems, Weiterstadt, Germany), using the following cycling protocol: $10 \min 95^{\circ} \mathrm{C}$

137 (denaturation); 40 cycles: $15 \mathrm{~s}$ at $95^{\circ} \mathrm{C}, 20 \mathrm{~s} 60^{\circ} \mathrm{C}, 40 \mathrm{~s} 72^{\circ} \mathrm{C}$. Relative gene expression to the

138 housekeeping gene HPRT, expressed as $\Delta \mathrm{C}_{\mathrm{t}}=\mathrm{C}_{\mathrm{t}}(\mathrm{pBD})-\mathrm{C}_{\mathrm{t}}(\mathrm{HPRT})$, was performed in order to

139 correct for the variance in amounts of cDNA input in the reactions.

$140 \quad 2.9$ Statistical analyses.

141 Statistical analyses were performed using SPSS version 15.0 for windows. All data were analyzed for

142 normality using the Shapiro-Wilk test. Differences between treated and control groups were

143 determined using the Mann-Whitney test. Significant differences were defined as $p<0.05$ 
144

145

146

147

148 The apical surface of IPEC-J2 cells was visualized using scanning electron microscopy (Figure 1).

149 The cell surface shows the presence of microvilli, characteristic of intestinal epithelial cells. The

150

151

152

153

154

155

156

157

158

159

160

161

162 The capacity of the porcine pathogens $S$. Typhimurium and four $S$. Choleraesuis strains to adhere and

163 invade IPEC-J2 cells was assessed. In these experiments, no difference in adhesion between these

164 bacteria was observed although large variations in adhesion were detected for all bacteria between

165 different experiments, resulting in relatively high standard deviations (Table 2). The invasion of

166 IPEC-J2 cells was comparable for all strains as well, except for $S$. Choleraesuis 977, which showed a

167 reduced capacity to invade the epithelial cells.

168

169

\section{Results}

microvilli are spread all over the apical surface of the cells, but density and structure differs somewhat between separate cells (Fig. 1A). In Figure 1.B, a S. Typhimurium is shown that is adhered to the cell surface. The picture shows that the flagella are attached to the microvilli of the intestinal cell. In Figure 1C and an enlargement thereof in 1D, the start of the invasion process is captured. The intestinal cell microvilli in the area surrounding the bacterium are shorter and deformed. The bacterium is engulfed and seems to invade the IPEC-J2 cell. The flagella are still visible while the bacterium enters the IPEC-J2 cell. Some unidentified balloon- or elongated shaped structures were also visible, most clearly shown in Fig 1C. These are considered cell debris, likely due to the experimental handling of the cell mixtures, since they were also observed in non-infected IPEC cells.

\subsection{Adhesion and invasion.}

$$
\text { reduced capacity to invade the epithelial cells. }
$$

\subsection{Susceptibility of Salmonella towards porcine $\beta$-defensin 2.}


170 The antimicrobial effect of pBD2 was assessed against $S$. Typhimurium and $S$. Choleraesuis 994.

171 Bacteria were incubated with pBD-2 and plated on TSA plates for colony counting. No significant

172 difference in susceptibility was observed between the two Salmonella strains (Figure 2). At $4 \mu \mathrm{g} / \mathrm{ml}$

173 pBD-2 the number of viable bacteria decreases dramatically and at 8-16 $\mu \mathrm{g} / \mathrm{ml}$ all Salmonella were

174 effectively killed by pBD-2. These minimal bactericidal concentration (MBC) values correspond to

175 approximately $4-8 \mu \mathrm{M} \mathrm{pBD}-2$, which is in the expected activity range of defensins.

176

3.4 Effect of infection on defensin gene expression.

In order to determine the effect of Salmonella infection on defensin regulation, IPEC-J2 cells were

infected with $S$. Typhimurium and $S$. Choleraesuis strains 994 and 997, which have comparable (944) and reduced (997) invasion characteristics to $S$. Typhimurium. The effect of infection on porcine $\beta$ defensin gene expression is shown in Figure 3. A highly significant upregulation of both pBD-1 $(\mathrm{p}<0.01$ at $\mathrm{t}=24 \mathrm{~h})$ and especially $\mathrm{pBD}-2(\mathrm{p}<0.01$ at $\mathrm{t}=24 \mathrm{~h})$ was observed when IPEC-J2 cells were infected with $S$. Typhimurium. The observed increase of 5 units in the $40-\Delta \mathrm{C}_{\mathrm{t}}$ value (Fig. 3B) corresponds to a 32-fold increase in gene expression for pBD-2. Induction of pBD-1 gene expression was approximately 8 -fold (three $40-\Delta \mathrm{C}_{\mathrm{t}}$ units) after $24 \mathrm{~h}$. In contrast, $S$. Choleraesuis (both strains) or sham treatment of IPEC-J2 cells did not lead to a significant increase in pBD-1 expression, indicating that this is a $S$. Typhimurium serovar specific process. The higher gene expression of pBD-2 for $\mathrm{S}$. Choleraesuis 997 infected cells compared to the control cells did actually reach statistical significance $(\mathrm{p}=0.024$ at $\mathrm{t}=24 \mathrm{~h})$, but the extent of induction and time dependency was completely different from that observed for S. Typhimurium. To further study the requirements for defensin upregulation, $S$. Typhimurium were killed before IPEC-J2 infection by either heat treatment or colistin treatment. Both methods resulted in complete killing of bacteria (results not shown). In addition, to detect whether $S$. Typhimurium secreted virulence factors or other secreted proteins were responsible for the observed $\beta$-defensin upregulating effect, a $S$. Typhimurium sample was allowed to grow in antibiotic-free IPEC-J2 cell medium for $3 \mathrm{~h}$ after which the bacteria were discarded through filtration, resulting in a 
198 from this sample as detected by plating on TSA plates (results not shown). As is shown in Figure 4,

199 heat or colistin treated bacteria were not capable of significantly inducing the expression of pBD-1 or

200 pBD-2, although a tendency ( $\mathrm{p}=0.063$ ) towards pBD-1 upregulation is observed for colistin treated

201 bacteria after $6 \mathrm{~h}$. Similarly, the secretome of viable $S$. Typhimurium did also not have an effect on

202 defensin gene expression. Overall, these results show that viable $S$. Typhimurium, and not a cell- or

203 secreted component of $S$. Typhimurium, are required for upregulation of porcine $\beta$-defensins. 


\section{Discussion}

205 From an immunological point of view, the epithelial lining of the intestine has long been considered solely a physical barrier to protect the underlining mucosa. Intestinal epithelial cells form a tightly

207 packed monolayer covered by a mucus layer that is difficult to penetrate for pathogenic bacteria.

208 Although this is still an important function of epithelial cells, their role in the innate immune response 209 upon infection, and their role in homeostasis of the gut microbiota is now generally being recognized 210 (Oswald, 2006). Intestinal epithelial cells produce cytokines and chemokines, which are crucial for 211 the recruitment and activation of immune cells. In addition, they produce and secrete effector 212 molecules such as $\beta$-defensins that can directly affect bacterial populations in the gut. Many of the 213 characteristics of intestinal epithelial cells are maintained within the IPEC-J2 cell line, including the 214 presence of microvilli and the expression of porcine beta defensins, described in this report. The 215 increasing number of reports using IPEC-J2 cells also shows that the cell line has established itself as 216 a useful model for intestinal research.

217 In this report we used the IPEC-J2 cells as a model to determine the effect of Salmonella infection on 218 porcine $\beta$-defensin regulation of intestinal epithelial cells. First, adhesion and invasion characteristics towards IPEC-J2 cells (Table 1) were tested for 4 Salmonella Choleraesuis strains and one Salmonella

220 Typhimurium. All tested Salmonella strains showed similar adhesion except for strain $S$. Choleraesuis 221 997, which had a reduced invasive activity (Table 2). This corresponds well to observations in other 222 cell lines where similar invasion of S. Choleraesuis and S. Typhimurium were detected in the human 223 colonic carcinoma cell line Caco-2, the human epithelial-like tumor cell line HEp-2, and rabbit ileal epithelia (Bolton et al., 1999, Bolton et al., 2000). However, in our studies, there was a relatively large variation observed in adhesion and invasion between experiments, which might have hampered detection of relatively small differences between Salmonella serovars. For $S$. Typhimurium, Schmidt

227 et al (Schmidt et al., 2008) have described an effect of growth phase of the bacterium on invasiveness

228 of cell lines showing that log phase $S$. Typhimurium have higher invasive activity than stationary phase bacteria. Although only log phase bacteria were used in this study, small day-to-day 
experimental differences could have affected the outcome. The actual growth phase of Salmonella could therefore, at least partially account for the high variance in the observed results.

233 S. Typhimurium reproducibly induced gene expression of both pBD-1 and pBD-2, while no or little effect was observed for the two $S$. Choleraesuis strains 994 and 997. These two $S$. Choleraesuis strains were chosen because of the similar (strain 994) and differing (strain 997) adhesion and invasion characteristic compared to $S$. Typhimurium, to possibly determine an effect of invasiveness on defensin regulation upon infection. The effect of $S$. Typhimurium on defensin expression in IPEC-J2 cells corresponds well to the effect observed in the ileal cell line IPI-2I, (Veldhuizen et al., 2006). The effect is apparently specific for $S$. Typhimurium, since Arcobacter Cryaerophilus and Salmonella

240 Enteritidis (in the IPI-2I cell line) or S. Choleraesuis (IPEC-J2) did not show the induced defensin

241 upregulation. However, studies by Sang et al also showed an increased pBD-1 expression in epithelial 242 cells upon infection with Escherichia coli and Listeria Monocytogenes (Sang et al., 2005). The time 243 course of pBD-1 expression was slightly different for ileal and jejunal cells. In the IPI-2I cell line maximum induction was observed after $6 \mathrm{~h}$ while the jejunal cell line IPEC-J2 showed the highest upregulation after $24 \mathrm{~h}$. Whether this reflects a true difference between jejunal and ileal cells or whether this is a cell line specific effect is not clear at this stage.

The fact that two related serovars such as $S$. Typhimurium and $S$. Choleraesuis have such a different effect on defensin expression of epithelial cells is remarkable. Skjolaas et al described a comparable difference in chemokine expression upon infection with these two Salmonella serovars (Skjolaas et al., 2006). In these studies, Il-8 and MIF (Macrophage migration inhibitory factor) expression was comparably regulated upon Salmonella infection but other innate immune genes such as CCL20 (CC chemokine ligand 20) and osteopontin expression was $S$. Typhimurium specific. It is known that in vivo the outcome of clinical disease is dependent on the Salmonella serovar, with $S$. Choleraesuis being more likely to cause systemic disease than $S$. Typhimurium (Reed et al., 1986). In a recent study

256 this difference was at least partially contributed to a different localization and replication rate of these

257 serovars in the porcine intestine in vivo. S. Choleraesuis persisted better in the mesenteric lymph 
nodes and showed a lower replication rate than S. Typhimurium in the epithelium layer (Paulin et al.,

259 2007). The described different response in terms of cytokine and defensin production of epithelial

260 cells to invasion of both Salmonella serovars could add to the pathogenic differences upon Salmonella

261 infection.

262 The experiments in this report indicated that viable $S$. Typhimurium are required to trigger the

263 induction of defensin gene expression, since bacterial or secreted components did not result in any

264 effect (Figure 4). This could mean that Salmonella has to invade the epithelial cell first before an

265 immune reaction is triggered, and would imply that cytosolic immunosensors, such as NOD or NOD-

266 like receptors could be involved (Delbridge and O'Riordan, 2007). However, that cannot easily

267 explain why $S$. Choleraesuis, which has a comparable invasion activity, does not elicit such a

268 response, since these receptors recognize ligands present in both Salmonellae. Elucidation of the

269 initial receptor and signal transduction pathways leading to defensin upregulation upon $S$.

270 Typhimurium infection could possibly resolve this issue. Besides providing insight into infection and

271 disease development in pigs, this could also lead to important clues on how to prevent Salmonella

272 infections. If the pathway leading to defensin production can be stimulated through simple feed

273 additives, the pig intestine would be well prepared for incoming pathogens, thereby preventing

274 infection. The potential of this approach is supported by recent studies that have shown that

275 probiotics, but also non-microbial compounds such as amino acids, vitamins and glucose, can induce

276 defensin expression (Barnea et al., 2008, Fehlbaum et al., 2000, Wang et al., 2004, Wehkamp et al.,

277 2004). The IPEC-J2 cell line provides a good and easy to use porcine model to test new feed additives

278 that could stimulate defensin production, or in a broader view, induce innate immunity in the porcine

279 intestinal tract.

280 In summary, we further validated IPEC-J2 epithelial cells as a useful model for intestinal research, by

281 visualizing microvilli on the surface of the cells and describing $\beta$-defensin gene expression. The

282 expression of $\beta$-defensins was induced upon $S$. Typhimurium but not $S$. Choleraesuis infection. This

283 induction is dependent on viable $S$. Typhimurium since bacterial or secreted components did not

284 affect gene expression of these $\beta$-defensins. 


\section{Acknowledgments}

287 The authors like to thank Mariska van Roosendaal for her help with the antimicrobial assays.

288 This work was supported by a research grant (Adaptation and Resistance Program) from the Animal

289 Sciences Group (Wageningen University and Research Centre) and the Faculty of Veterinary

290 Medicine (Utrecht University), The Netherlands. 
Barnea, M., Madar, Z., Froy, O., 2008. Glucose and insulin are needed for optimal defensin expression in human cell lines. Biochem. Biophys. Res. Commun. 367, 452-456. Beutler, B., 2004. Innate immunity: an overview. Mol. Immunol. 40, 845-859.

Bolton, A. J., Martin, G. D., Osborne, M. P., Wallis, T. S., Stephen, J., 1999. Invasiveness of Salmonella serotypes Typhimurium, Choleraesuis and Dublin for rabbit terminal ileum in vitro. J. Med. Microbiol. 48, 801-810. Bolton, A. J., Osborne, M. P., Stephen, J., 2000. Comparative study of the invasiveness of Salmonella serotypes Typhimurium, Choleraesuis and Dublin for Caco-2 cells, HEp-2 cells and rabbit ileal epithelia. J. Med. Microbiol. 49, 503-511.

Chiu, C. H., Su, L. H., Chu, C., 2004. Salmonella enterica serotype Choleraesuis: epidemiology, pathogenesis, clinical disease, and treatment. Clin. Microbiol. Rev. 17, 311322.

Delbridge, L. M., O'Riordan, M. X., 2007. Innate recognition of intracellular bacteria. Curr. Opin. Immunol. 19, 10-16.

Fehlbaum, P., Rao, M., Zasloff, M., Anderson, G. M., 2000. An essential amino acid induces epithelial beta -defensin expression. Proc. Natl. Acad. Sci. U S A 97, 12723-12728. Fraser, J. N., Davis, B. L., Skjolaas, K. A., Burkey, T. E., Dritz, S. S., Johnson, B. J., Minton, J. E., 2007. Effects of feeding Salmonella enterica serovar Typhimurium or serovar Choleraesuis on growth performance and circulating insulin-like growth factor-I, tumor necrosis factor-alpha, and interleukin-1beta in weaned pigs. J. Anim. Sci. 85, 1161-1167. Hendriksen, S. W., Orsel, K., Wagenaar, J. A., Miko, A., van Duijkeren, E., 2004. Animal-tohuman transmission of Salmonella Typhimurium DT104A variant. Emerg. Infect. Dis. 10,

315 Lehrer, R. I., 2004. Primate defensins. Nat. Rev. Microbiol. 2, 727-738.

316 Oswald, I. P., 2006. Role of intestinal epithelial cells in the innate immune defence of the pig intestine. Vet. Res. 37, 359-368. 

replication of Salmonella enterica serovars Typhimurium and Choleraesuis in porcine intestinal mucosa and nodes is associated with their differential virulence. Infect. Immun. 75, 3950-3960.

Reed, W. M., Olander, H. J., Thacker, H. L., 1986. Studies on the pathogenesis of Salmonella typhimurium and Salmonella choleraesuis var kunzendorf infection in weanling pigs. Am J Vet. Res. 47, 75-83.

Sang, Y., Patil, A. A., Zhang, G., Ross, C. R., Blecha, F., 2006. Bioinformatic and expression analysis of novel porcine beta-defensins. Mamm. Genome 17, 332-339. Sang, Y., Ramanathan, B., Ross, C. R., Blecha, F., 2005. Gene silencing and overexpression of porcine peptidoglycan recognition protein long isoforms: involvement in beta-defensin-1 expression. Infect. Immun. 73, 7133-7141. Jores, J., Tachu, B., Kleta, S., Blikslager, A., Tedin, K., Wieler, L. H., 2006. Characterization of a porcine intestinal epithelial cell line for in vitro studies of microbial pathogenesis in swine. Histochem. Cell. Biol. 125, 293-305.

Schmidt, L. D., Kohrt, L. J., Brown, D. R., 2008. Comparison of growth phase on Salmonella enterica serovar Typhimurium invasion in an epithelial cell line (IPEC J2) and mucosal explants from porcine small intestine. Comp. Immunol. Microbiol. Infect. Dis. 31, 63-69. Schwartz, K., J., 1999. Salmonellosis. 8th ed.. Iowa State Univ Ames, Iowa, serovars Typhimurium (ST) and Choleraesuis (SC) on chemokine and cytokine expression in swine ileum and jejunal epithelial cells. Vet. Immunol. Immunopathol. 111, 199-209. Veldhuizen, E. J.A., Hendriks, H. G., Hogenkamp, A., van Dijk, A., Gaastra, W., Tooten, P. C., Haagsman, H. P., 2006. Differential regulation of porcine beta-defensins 1 and 2 upon Salmonella infection in the intestinal epithelial cell line IPI-2I. Vet. Immunol. Immunopathol. 114, 94-102. 
Veldhuizen, E. J.A., Rijnders, M., Claassen, E. A., van Dijk, A., Haagsman, H. P., 2008.

Porcine beta-defensin 2 displays broad antimicrobial activity against pathogenic intestinal bacteria. Mol. Immunol. 45, 386-394.

Veldhuizen, E. J. A., van Dijk, A., Tersteeg, M. H.G., Kalkhove, S. I., van der Meulen, J.,

Niewold, T. A., Haagsman, H. P., 2007. Expression of beta-defensins pBD-1 and pBD-2

along the small intestinal tract of the pig: Lack of upregulation in vivo upon Salmonella typhimurium infection. Mol. Immunol. 44, 276-283.

Wang, T. T., Nestel, F. P., Bourdeau, V., Nagai, Y., Wang, Q., Liao, J., Tavera-Mendoza, L.,

D3 is a direct inducer of antimicrobial peptide gene expression. J. Immunol. 173, 2909-2912. 2004. NF-kappaB- and AP-1-mediated induction of human beta defensin-2 in intestinal epithelial cells by Escherichia coli Nissle 1917: a novel effect of a probiotic bacterium. Infect. Immun. 72, 5750-5758.

Figure legends.

368 Salmonella Typhimurium attached to the cell surface of an IPEC-J2 cell. (C) Invasion of Salmonella,

369 the bacterium is engulfed by the IPEC-J2 cell apical surface. (D) Enlargement of the invasion process 370 shown in $1 \mathrm{C}$. 
371 Fig. 2. Concentration dependent killing of (A) Salmonella Typhimurium and (B) Salmonella

372 Choleraesuis 994 by pBD-2. Salmonella were incubated with pBD-2 for 3 h, after which remaining

373 viable bacteria were detected using colony counting.

375 Fig 3. Effect of Salmonella infection of IPEC-J2 cells on the gene expression of pBD-1 and pBD-2.

376 IPEC-J2 cells were Sham treated (C) or infected with Salmonella Typhimurium (ST), Salmonella

377 Choleraesuis 994 (SC994) or Salmonella Choleraesuis 997 (SC997). Shown are mean expression

378 values $(\mathrm{n} \geq 4)$ expressed as 40 minus the corrected threshold Ct value, plus SEM; 6, 12 and $24 \mathrm{~h}$ after

379 infection. Experiments were (minimally) performed in duplicate and repeated on 2 separate days. '*'

380 indicates significant differences $(\mathrm{p}<0.05)$ compared to the control levels at the same time point. '**'

381 indicates $\mathrm{p}<0.01$.

383 Fig. 4. Effect of viability of $S$. Typhimurium on the expression of pBD-1 and pBD-2 upon infection of

384 IPEC-J2 cells. S. Typhimurium were killed by heat inactivation or colistin treatment. Secreted proteins of $S$. Typhimurium were collected by filtration after $1 \mathrm{~h}$ incubation of $S$. Typhimurium in

386 IPEC-J2 cell medium. 'C' $=$ sham treated cells, 'ST'= S. Typhimurium infected cells. 'Heat' = heat-

387 killed $S$. Typhimurium, 'Col'= Colistin killed $S$. Typhimurium, 'Sec'= secreted protein fraction of $S$.

388 Typhimurium. Shown are mean expression values ( $\mathrm{n} \geq 4$ ), expressed as 40 minus the corrected

389 threshold Ct value, plus SEM; 6 and $24 \mathrm{~h}$ after infection. Experiments were (minimally) performed in

390 duplicate and repeated on 2 separate days. ' $*$ ' indicates significant differences $(\mathrm{p}<0.05)$ compared to

391 the control levels at the same time point. '**' indicates $\mathrm{p}<0.01$. 
Table 1. Primer and probe sequences used for quantitative PCR

$\begin{array}{lll}\text { Gene } & \text { Sequence } & \text { Concentration }\end{array}$

HPRT Forw. tggaaagaatgtcttgattgttgaag $300 \mathrm{nM}$

Rev. atctttggattatgctgcttgacc $\quad 300 \mathrm{nM}$

Probe acactggcaaaacaatgcaaacetgct $200 \mathrm{nM}$

pBD-1 Forw. tgccacaggtgcegatct $\quad 400 \mathrm{nM}$

Rev. ctgttagctgcttaaggaataaaggc $400 \mathrm{nM}$

Probe tttggagcacacttgcceggcata $200 \mathrm{nM}$

pBD-2 Forw. ccagaggtccgaccactaca $\quad 300 \mathrm{nM}$

Rev. ggtccettcaatcctgttgaa $\quad 300 \mathrm{nM}$

Probe ctgcaacttctccectgeccg $\quad 200 \mathrm{nM}$

Table 2. Adhesion and invasion of Salmonella Typhimurium and Choleraesuis in IPEC-J2 Cells. Data are expressed as the number of bacteria per IPEC-J2 cell.

\begin{tabular}{llllll}
\hline & S. Choleraesuis & S. Choleraesuis & S. Choleraesuis & S. Choleraesuis & S. Typhimurium \\
& 994 & 995 & 996 & 997 & \\
& & & & & \\
\hline Adhesion & $2.35 \pm 1.68$ & $1.83 \pm 0.47$ & $1.49 \pm 0.62$ & $1.49 \pm 0.25$ & $1.94 \pm 1.04$ \\
& & & & & \\
Invasion & $0.98 \pm 060$ & $0.70 \pm 0.37$ & $0.65 \pm 0.31$ & $0.14 \pm 0.07$ & $0.94 \pm 0.57$ \\
& & & & & \\
\hline
\end{tabular}



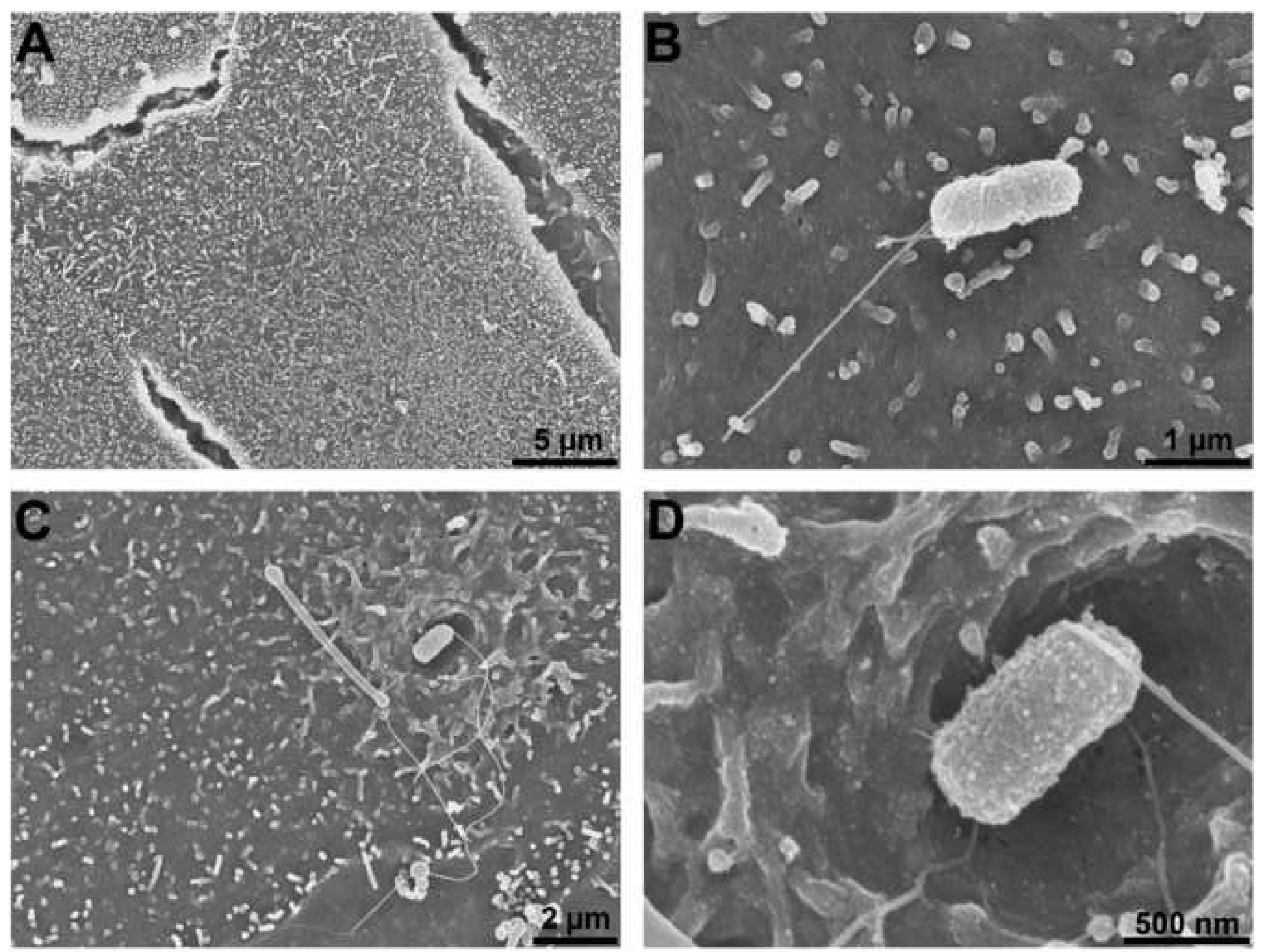

rage 20 or 23 

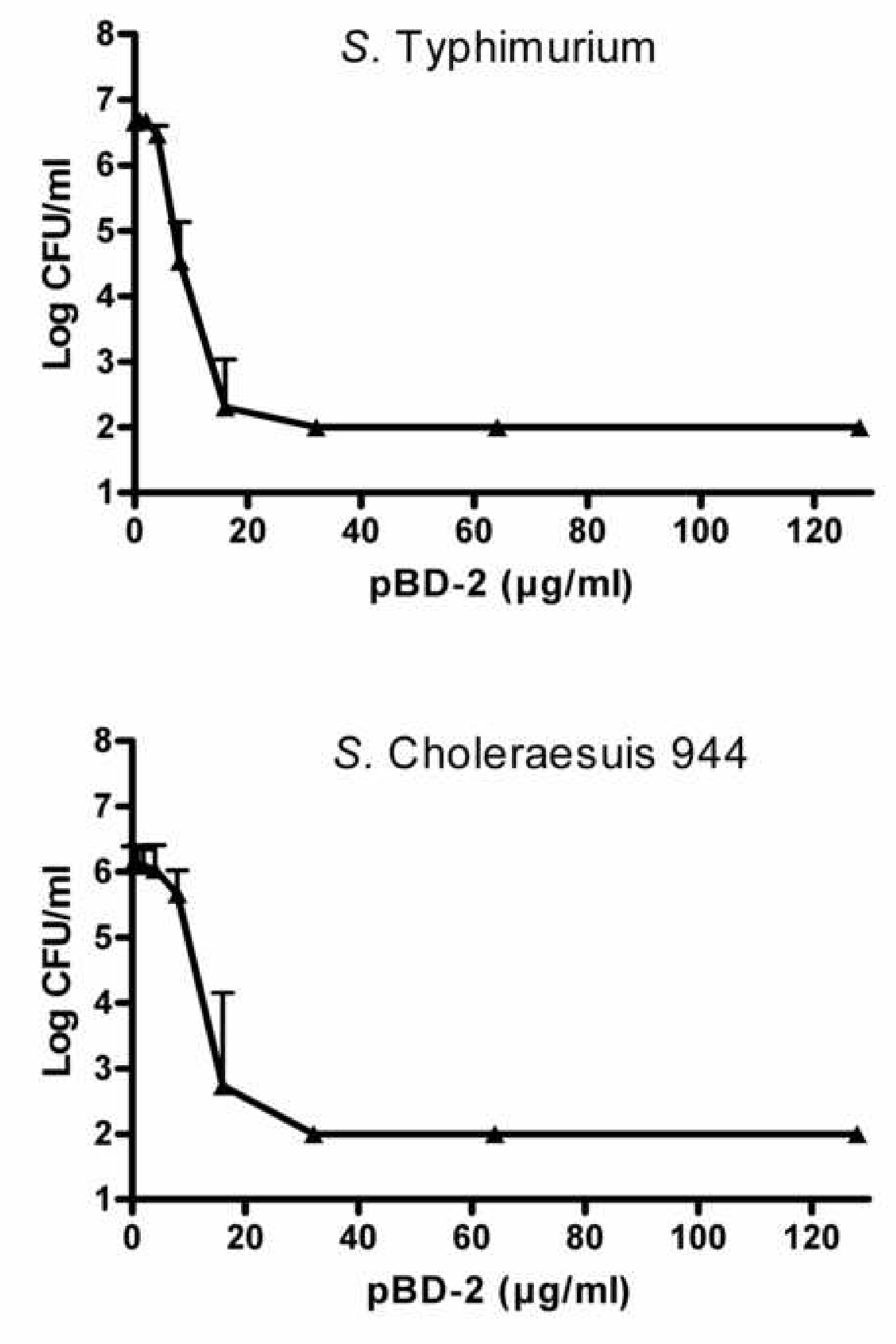

\section{pBD-2 ( $\mu \mathrm{g} / \mathrm{ml})$}

西



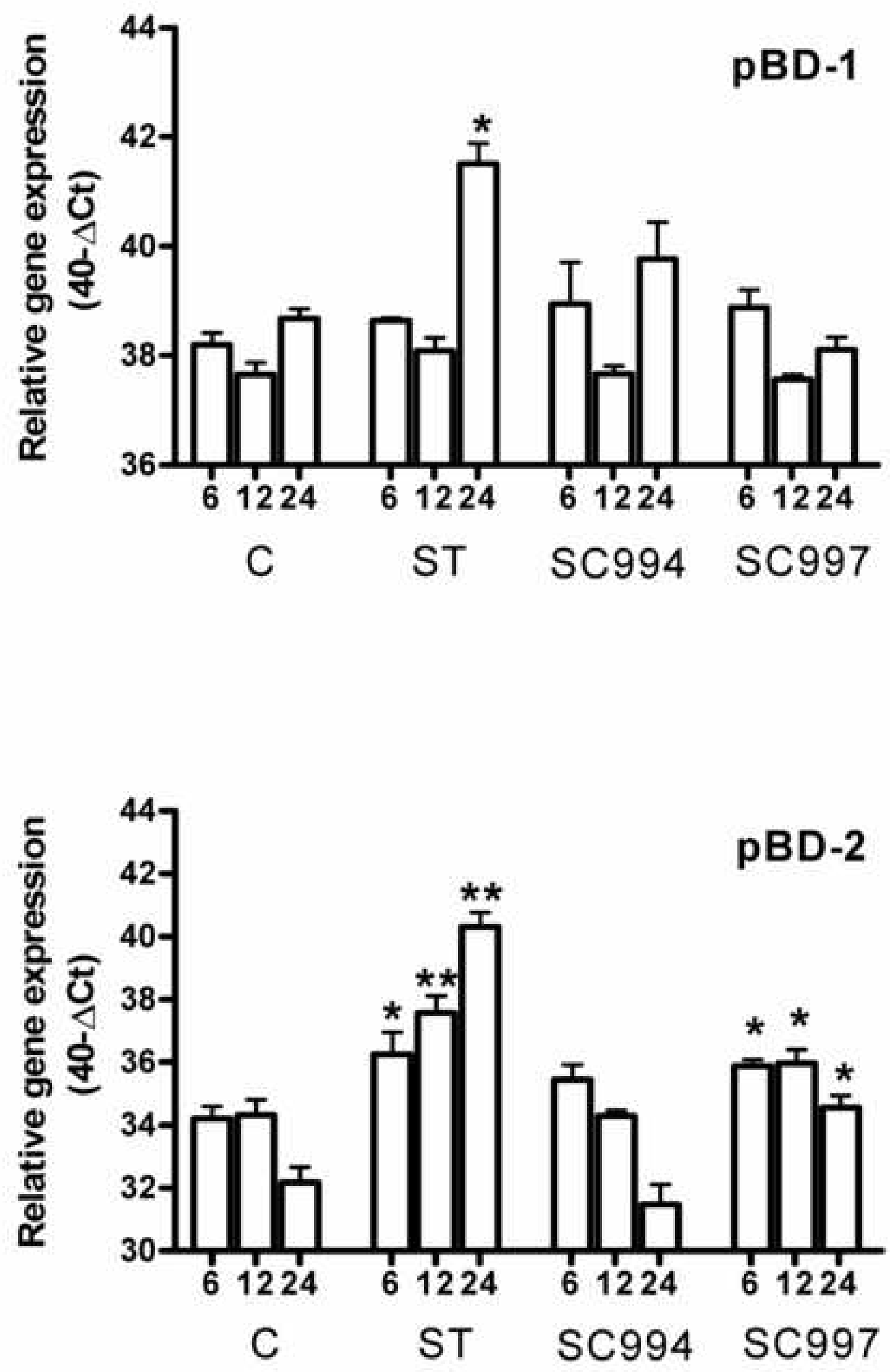

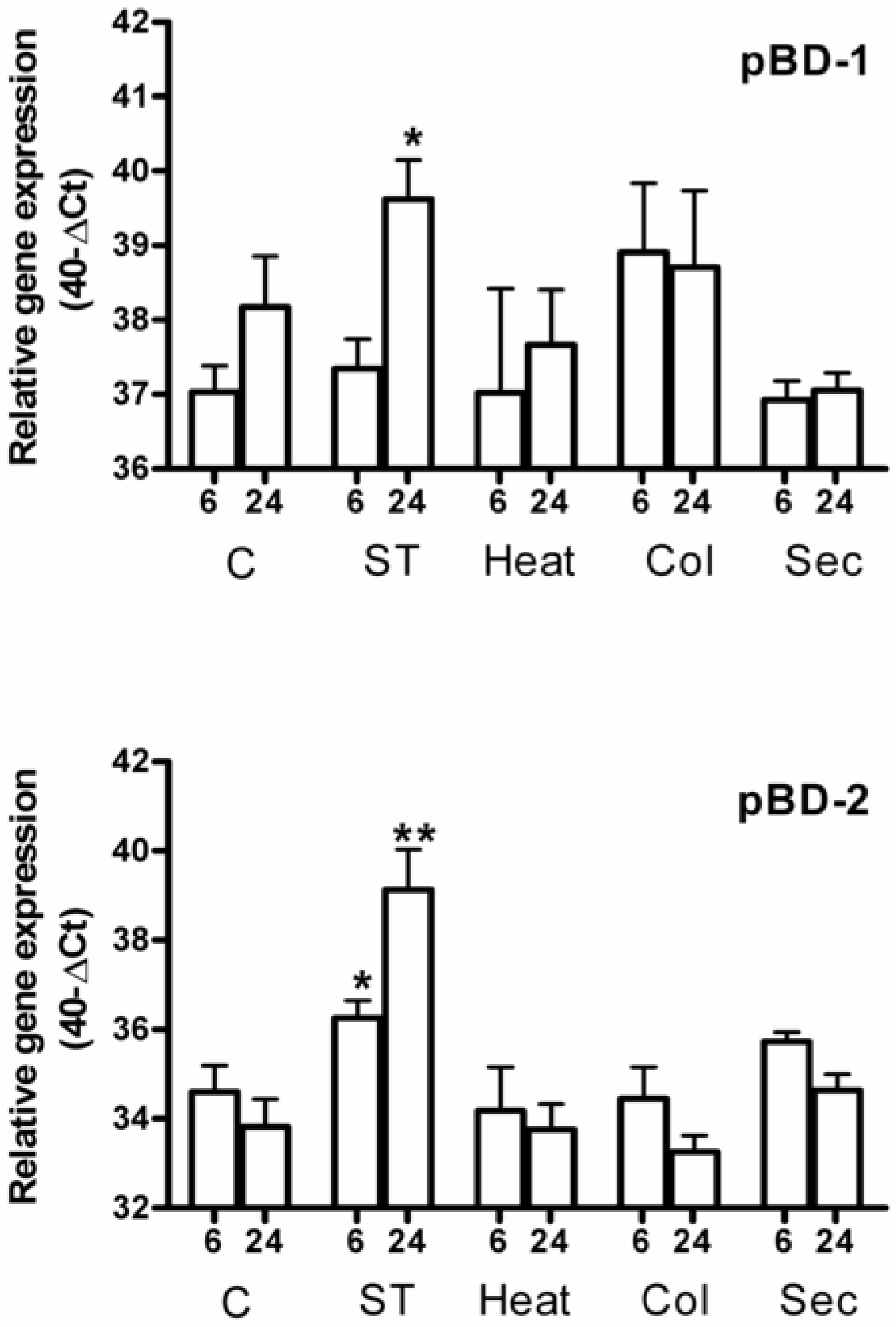